Letters to the Editor

\section{Spinal sensory radiculopathy due to Angiostrongylus cantonensis infection}

Sir,

In the January 1991 edition of Postgraduate Medical Journal, we authored an article entitled 'Spinal sensory radiculopathy due to Angiostrongylus cantonensis infection', in which we stated, that to our knowledge, this was the first published report of eosinophilic meningitis originating in Fiji.'

It has been drawn to our attention that there are 2 previous publications describing a number of cases diagnosed in Fiji between mid-1982 and 1984..$^{2,3}$

\section{Michael Whitby \\ Department of Infectious Diseases and Infection Control, \\ Princess Alexandra Hospital, Ipswich Road, \\ Woolloongabba, Brisbane Q4102,} Australia

\section{References}

1. Wood, G., Delamont, S., Whitby, M. \& Boyle, R. Spinal sensory radiculopathy due to Angiostrongylus cantonensis infection. Postgrad Med J 1991, 67: 70-72.

2. Ram, P., Kapadia, V., Singh, K.P. \& Seruvatu, L. Eosinophilic meningitis: First confirmed case of fatal human Angiostrongyliasis in Fiji. Fiji Med J 1985, 13: 104- 107.

3. Beg, M.F., Kapadia, V., Naidu, V., Mudalier, J. \& Ram, P. Eosinophilic meningitis in Fiji. Fiji Med J 1985, 13: 98-102.

\section{Gynaecomastia and extragonadal symptoms leading to diagnosis delay of germ cell tumours in young men}

Sir,

I read with great interest the report of Cantwell and associates.' I was particularly interested in the fact that both men described in their report were offered reduction mammoplasty without regard to the possibility of occult (or obvious) testicular cancer.

We have recently reported a case of inappropriate mastectomy for gynaecomastia in an undiagnosed testicular cancer patient. ${ }^{2}$ Our case involved a 31 year old white male who had noted progressive breast tenderness and gynaecomastia over 4 months without seeking medical attention. He finally saw a physician's assistant and by this time some initial vague scrotal symptoms had resolved and he failed to recount this to the examiner. No genitourinary examination was performed and no evaluation for testicular cancer was entertained. He was referred to a general surgeon who also did not evaluate for testis cancer and performed a bilateral subcutaneous mastectomy. Two months later, during a military physical examination, he was given and read a brochure on testicular cancer and testicular self-examination. $\mathrm{He}$ thereafter told of his prior scrotal symptoms and the examiner detected on obvious right testicular mass. The serum beta-human choronic gonadotropin was elevated to $42,600 \mathrm{IU} / \mathrm{ml}$. Further evaluation revealed clinical IIB mixed non-seminomatous germ cell tumour for which the patient received chemotherapy and a retroperitoneal lymphadenectomy. Fortunately, the patient remains free of disease 1 year from this episode.

To our surprise, unnecessary mastectomy for testicular cancer-induced gynaecomastia does not appear to be rare. Including our case and that of Cantwell et al., we have found 7 cases of this inappropriate surgery in unrecognized testis cancer patients. ${ }^{3-6}$ We strongly agree with Cantwell and colleagues that germ cell tumours should be considered in the differential diagnosis of gynaecomastia and that young men with gynaecomastia should have testicular examinations and be carefully questioned about past testicular abnormalities. In addition to the impact of delay in diagnosis which we know is significant, ${ }^{7}$ gynaecomastia due to unrecognized testis cancer may also lead to unnecessary surgical intervention.

Judd W. Moul Attending Urologic-Oncologis Walter Reed Army Medical Cente? Washington D.C. and Assistant Professor of Surger Uniformed Services University of the Health Sciences, 4301 Jones Bridge Road, Bethesda, MD 20814-4799, U.S.A.

\section{References}

1. Cantwell, B.M.J., Richardson, P.G.G. \& Campbell, S.J. Gynaecomastia and extra-gonadal symptoms leading to diagnosis delay of germ cell tumours in young men. Postgrad Med 1991, 67: 675-677.

2. Moul, J.W. \& Moellman, J.R. Unnecessary mastectomy for gynecomastia in a testicular cancer patient. Military Med (in press).

3. Prout, G.R. \& Griffin, P.P. Testicular tumors: delay in diagnosis and influence on survival. Am Fam Physician 1984, 29: 205-209.

4. Gabrilove, J.L. \& Furukawa, H. Gynecomastia in association with complex tumor of the testis secreting chorionic gonadotropin: studies on the testicular venuous affluent. $J$ Urol 1984, 131: $348-350$.

5. Valensi, P., Coussieu, C., Pauwels, A. et al. Feminizing Leydig N cell tumor: endocrine and incubation studies. $J$ Endocrinol $\mathrm{N}$ Invest 1987, 10: 187-193.

6. O'Donovan, J.J., Terry, T.R. \& Williams, G. Occult Leydig cell testicular tumor presenting with gynaecomastia. $J R$ Soc Med 1988, 82: 49-50.

7. Moul, J.W., Paulson, D.F., Dodge, R.K. \& Walther, D.J. Delay in diagnosis and survival in testicular cancer: impact of effective therapy and changes during 18 years. J Urol 1990, 143: $520-525$ 